\title{
Measured Energy Savings from the Application of Reflective Roofs in 2 Small Non-Residential Buildings
}

\author{
Hashem Akbari* \\ Heat Island Group \\ Lawrence Berkeley National Laboratory \\ Berkeley, CA 94720 \\ Received 1 August 2001
}

\begin{abstract}
Energy use and environmental parameters were monitored in two small $\left(14.9 \mathrm{~m}^{2}\right)$ non-residential buildings during the summer of 2000. The buildings were initially monitored for about $11 / 2$ months to establish a base condition. The roofs of the buildings were then painted with a white coating and the monitoring was continued. The original solar reflectivities of the roofs were about $26 \%$; after the application of roof coatings the reflectivities increased to about $72 \%$. The monitored electricity savings were about $0.5 \mathrm{kWh}$ per day (33 $\mathrm{Wh} / \mathrm{m}^{2}$ per day). The estimated annual savings are about $125 \mathrm{kWh}$ per year $\left(8.4 \mathrm{kWh} / \mathrm{m}^{2}\right)$; at a cost of $\$ 0.1 / \mathrm{kWh}$, savings are about $\$ 0.86 / \mathrm{m}^{2}$ per year. Obviously, it costs significantly more than this amount to coat the roofs with reflective coating, particularly because of the remote locations of these buildings. However, since the prefabricated roofs are already painted green at the factory, painting them a white (reflective) color would bring no additional cost. Hence, a reflective roof saves energy at no incremental cost.
\end{abstract}

\section{Introduction}

Cool roofs reflect most of the incoming sunlight and keep the roof surface at a lower temperature than that of regular (hot) roofs (roofs that absorb most of the incoming radiation). A lower roof surface temperature leads to lower heat conduction into the building and hence reduces cooling loads of the building.

\footnotetext{
*Corresponding Author: Fax: 510-486-4287; E-mail: h_akbari@lbl.gov.
} 
Several field studies have documented measured energy savings that result from increasing the solar reflectivity of roofs. Akbari et al. reported on monitored cooling-energy savings of $46 \%$ and peak-power savings of $20 \%$ by increasing the roof albedo of two identical school bungalows in Sacramento [1]. More recent studies have documented measured savings of $12-18 \%$ in two commercial buildings in California [2] and an average of $19 \%$ in eleven Florida residences [3] by applying reflective coatings on roofs. Parker et al. monitored seven retail stores within a strip mall in Florida before and after applying a high-albedo coating to the roof and measured a $25 \%$ drop in seasonal cooling-energy use [4]. Hildebrandt et al. observed daily airconditioning (AC) savings of 17\%, 26\%, and 39\% in an office, museum, and hospice with high-albedo roofs in Sacramento [5]. In an education building, Akridge reported savings of $28 \%$ by painting the galvanized roof with a white acrylic caoting [6]. An office building in southern Mississippi was shown to save $22 \%$ after the application of a highly reflective coating [7]. Simpson and McPherson measured AC savings in the range of $5 \%-28 \%$ in several 1/4-scale models in Tucson AZ [8].

In addition to field studies, computer simulations of cooling-energy savings from increased roof albedo have been documented in many studies of residential and commercial buildings [3,9-11]. Konopacki et al. estimated the direct energy savings potential from high-albedo roofs in eleven U.S. metropolitan areas [12]. The results showed that three major building types account for over $90 \%$ of the annual electricity and monetary savings: old residences (55\%), new residences (15\%), and old/new office buildings and retail stores together (25\%). Furthermore, these three building types account for 93\% of the total air-conditioned roof area. The regional savings were a function of energy savings in the air-conditioned building, stock of residential and commercial buildings, percentage of buildings that were air-conditioned, and the number of floors per building (roof area). Populous cities with an older low-rise building stock, in hot and sunny climates, and with a high level of AC saturation provided the highest savings potential for heat-island reduction measures. Metropolitan-wide savings were as much as $\$ 37 \mathrm{M}$ for Phoenix and $\$ 35 \mathrm{M}$ in Los Angeles and as low as $\$ 3 \mathrm{M}$ in the heating-dominated climate of Philadelphia. The analysis of the urban scale energy savings potentials is further refined for three cities: Baton Rouge, LA; Sacramento, CA; and Salt Lake City, UT [13]. 
The American Telephone and Telegraph Company (AT\&T) maintains hundreds of small optical regeneration buildings every $20 \mathrm{~km}$ along its national network of fiber-optic communications lines. These "regen" buildings contain optical amplification equipment that maintains the signal strength of digital communications sent through the fiber-optic cables. In this study, we evaluated the impact of covering the roofs of these buildings with a white coating in order to reduce the cooling-energy usage of the buildings. During the period from June to October 2000, we monitored the energy use in these buildings and conducted experiments to quantify the impact of roof reflectivity on the cooling-energy use of the buildings.

\section{Description of Buildings}

We report results for two sites monitored across Nevada, U.S.:

- Battle Mountain (200 miles east of Reno)

- Carlin (60 miles east of Battle Mountain).

Each regen building consists of a $3.0 \mathrm{~m}$ wide $\mathrm{x} 4.9 \mathrm{~m}$ wide $\mathrm{x} 3.0 \mathrm{~m}$ high prefabricated concrete structure with one access door (see Figure 1). The building shell consists of $12.5 \mathrm{~cm}$ thick concrete with an exposed aggregate finish. The inside of the walls have $5 \mathrm{~cm}$ of isocyanurate foam covered with $1.25 \mathrm{~cm}$ gypsum wallboard. The ceiling consists of $7.5 \mathrm{~cm}$ of isocyanurate foam insulation covered with $1.25 \mathrm{~cm}$ gypsum wallboard. Above the ceiling is a $0.6 \mathrm{~m}$ high attic passively ventilated by a $25 \mathrm{~cm}$ x $36 \mathrm{~cm}$ louvered opening at each gable end. The roofs are painted gray-green.

Each regen building contains optical amplification equipment with a connected load of approximately $2.5 \mathrm{~kW}$. The equipment operates on 48 voltage DC supplied by a bank of lead-acid batteries that are continually charged by the 120 voltage AC supply. The buildings conditions are maintained between $18.3^{\circ} \mathrm{C}$ (heating setpoint temperature) and $26.7^{\circ} \mathrm{C}$ (cooling setpoint temperature) by an environmental control panel that operates two through-the-wall packaged terminal air-conditioners and a resistance heater. The primary air-conditioner is used to maintain $26.7^{\circ} \mathrm{C}$ while the secondary air-conditioner is used only when the interior temperature exceeds $29.4^{\circ} \mathrm{C}$. A seven-day interval timer set for $31 / 2$ days selects one of the two air- 
conditioners alternately as the primary unit so that they incur an approximately equal number of operating hours.

The rated AC characteristics for these buildings are summarized in Table 1. None of the AC systems have an economizer cycle.

\section{Roof Surface Albedo}

For the existing roofs, a one-time measurement of roof surface albedo was performed at each site using a pyranometer to measure total downward and upward radiation parallel to the roof. Three measurements were taken at the center of each side of the roof and averaged. The roof albedo measurements for each site were highly consistent with the overall average measured at $26 \%$.

The roofs of the buildings were covered with a white coating during July 26-28. Our initial plan was to measure the reflectivity of the white coating during the decommissioning of the monitoring equipment (planned for the first week of October). Unfortunately, at the time of the decommissioning the sky was cloudy and we were only able to measure the albedo of the coated roof for a third identical building (not reported in this paper) at $72 \%$. However, we believe that since all the roofs are of the same material with the same roughness, the reflectivity of all coated roofs after about 2 months is about $72 \%$. The reflectance of the freshly coated roof was bout $80 \%$.

\section{Instrumentation, Data Acquisition Systems, and Analysis Technique}

Data monitoring equipment was installed on June 7-9, 2000. Table 2 shows the 13 data points installed with their locations shown in Figure 2. All variables were measured every 15 seconds with the average values recorded on a 15-minute basis. Data were downloaded nightly via modem.

A Data Electronics DT50 data logger and a modem were installed on the wall inside each regen building. All sensor cables were pulled to the logger box through a penetration in the ceiling. The modem was connected to the existing phone line for nightly data downloads. 
Two roof surface temperature sensors were installed, one in the middle of each side of the roof. The sensors are type $\mathrm{T}$ foil thermocouples connected to special limits of error extension wire. The sensors were epoxied to the roof surface and then painted to match the existing roof color.

A weather tower was attached to the side of the building, with the top $0.6 \mathrm{~m}$ above the peak of the roof. Mounted to the tower are an R.M. Young model 41372VF relative humidity/temperature probe in a gill radiation shield, an R.M. Young model 05103-11 wind monitor, and a Licor model LI-200SZ silicon pyranometer.

Temperature sensors were installed directly below each of the two roof surface temperature sensors, in the attic space, and inside of the building. The underside sensors were epoxied to the surface similarly to the roof surface sensors. The attic air temperature sensor was mounted in a shielded box to shield it from radiant transfer from the attic surfaces. The inside temperature sensor was mounted on the wall next to the environmental control panel.

Two Continental Control Systems WNA-1P-240P power transducers were attached to the main building supply and both air-conditioning supplies. The transducers read both phases of current and voltage and provide 4 pulses per watt-hour.

At both buildings, data were collected at 15-minute intervals. On a regular basis, the data were remotely downloaded to our computers for inspection and analysis. The data were frequently inspected for accuracy. Questionable and missing data were identified and flagged. In some cases, data indicated variations from standard operation of the buildings (e.g., lights were left on for a few days) and actions were taken to remedy the problem (e.g., lights were turned off).

The first step in the analysis was to aggregate the validated 15-minute data into hourly and daily data for solar intensity and for cooling and total energy-use. The temperature data were averaged to yield hourly and daily variables. In this process, questionable and missing data were identified and excluded from the analysis. Less than $1 \%$ of the data were missing or questionable. 
The parameters that can affect air-conditioning energy use include outside temperature, inside temperature, solar heat gain, internal loads, relative humidity, and wind speed. A systematic multi-variant regression analysis was performed in order to determine the sensitivity of the air-conditioning electricity use to these environmental parameters. The analysis was performed for the initial conditions before the roof was coated with a reflective white coating (defined as Pre period) and for the conditions after the roof was coated (defined as Post period). These regressions allowed normalizing the Pre and Post conditions for all parameters before making an attempt to estimate savings from the application of white coating.

\section{Analysis and Results}

\section{Temperature Data}

Figure 3 shows the hourly temperature plots of the roof surface, under-roof surface, attic air, and outside air for the three sites monitored. The dramatic impact of the roof coatings on the surface, undersurface and attic-air temperatures are obvious. Before the roof coatings were applied, the roof surface temperatures were typically about $14-19 \mathrm{~K}$ higher than the ambient air temperature. The under-roof and attic temperatures were also consistently higher than the ambient air temperature. Even during the evening and early morning hours the roof, under-roof, and attic air were about $6 \mathrm{~K}$ higher than ambient air; primarily because of the thermal storage effects of the concrete roofs. After the roof coatings were applied, the roof-surface temperatures during daytime were about $19-22 \mathrm{~K}$ cooler than pre-retrofit conditions. In the morning hours, the roof-surface temperatures are as much as $7 \mathrm{~K}$ cooler than the ambient air temperatures, gradually warming to ambient temperature. This is mainly because of the combination of radiative heat loss to the clear sky and the thermal storage capacity of the concrete roof slab. This radiative heat loss occur both daytime and nighttime at an average of about $60-70 \mathrm{~W} / \mathrm{m}^{2}$. Because of the thermal inertia, during the day, the temperature of the concrete roof slab rises far slower than the ambient temperature, since the roof with a high reflectivity absorbs less of the sunshine than the dark roof. During early morning hours, the roof-surface temperature is slightly (about $1-2 \mathrm{~K}$ ) warmer than the ambient air. The under-roof and attic-air temperatures are very close to each 
other; during the day they are about $8-10 \mathrm{~K}$ cooler than the ambient air, during the night about $3 \mathrm{~K}$ warmer than the ambient air.

Figure 4 is a plot of average daily and hourly temperature differences between roof surface, underroof, attic air (Trs, Tru, and Taa), and ambient temperature (temperature rise), for both sites. It is evident that the average daily temperature rise for the roof surface before coating is $\sim 7-8 \mathrm{~K}$. After coating, the average daily roof surface temperature is $\sim 2 \mathrm{~K}$ cooler than the ambient air. The plot also shows changes in the temperatures of the roof layers on a diurnal basis.

A quick estimate of the impact of the roof coating on air-conditioning energy use can be obtained from the analysis of the heat-flow contribution through the roof. Data indicate that the average daily attic temperature before application of the roof coating is about $5 \mathrm{~K}$ warmer than the daily ambient temperature. After the application of the roof coating, the daily attic temperature is about $2 \mathrm{~K}$ cooler than the ambient temperature. This would yield an average daily temperature reduction of the attic-air temperature by about 7K. (Note that working with the temperature rise in the attic we are basically normalizing for ambient conditions before and after application of reflective roofs.) Given the ceiling R-value of $3.2 \mathrm{~K} . \mathrm{m}^{2} / \mathrm{W}$ (R-18; $7.5 \mathrm{~cm}$ of insulation) and the inside and outside air film resistances of about $0.2 \mathrm{~K} . \mathrm{m}^{2} / \mathrm{W}$ (for a total ceiling Rvalue of $3.6 \mathrm{~K} \cdot \mathrm{m}^{2} / \mathrm{W}$ ), the reduction in the heat conducted through the roof is about $0.7 \mathrm{kWh}$ per day. Assuming a daily average air-conditioning COP of about 1.7 (see Figure 5). For Battle Mountain the average daily internal load is about $60 \mathrm{kWh}$ and the average AC use is about $35 \mathrm{kWh}$; hence, a rough estimate of average daily COP is about $60 / 35=1.7$. For this rough estimate of COP, we have ignored the cooling load from the building envelop, about $2-3 \mathrm{kWh}$ per day.), the net daily reduction in air-conditioning use is estimated to be roughly $0.4 \mathrm{kWh}$ per day.

Also, it is important to note that the daily air-conditioning energy use for each of these buildings is about 35-40 kWh (see the following section). Savings of about $0.5 \mathrm{kWh}$ per day because of the reflective roofs amount to about $1 \%$ of the total air-conditioning use. Documenting measured savings in the order of $1 \%$ is expected to be challenging. 


\section{Air-Conditioning and Total Building Electricity Use}

In these buildings, we monitored air-conditioning energy use and whole-building (total) energy use. The energy use for the equipment inside the buildings was calculated by subtracting the air-conditioning from the whole-building energy use. Figure 5 shows the whole-building, air-conditioning, and non-airconditioning energy use data on a daily basis for the entire monitoring period, and on an hourly basis for a week before and after the roof coatings were applied.

Data for both sites show a very constant level of energy use for non-air-conditioning equipment. This pattern of energy use for equipment was expected, since this equipment is in operation continuously. There are periods of exceptions to this constant energy use pattern. During most of the month of June (6/10-6/29), the building in Battle Mountain was consuming about $7 \mathrm{kWh}$ per day more in equipment use than the rest of the monitoring duration. In both sites, the energy use for air-conditioning shows no apparent change after the application of the roof coating.

\section{Analysis of Daily Air-Conditioning Energy Use}

To estimate the changes in air-conditioning energy use, we regressed the daily AC energy use against

many variables, including outside temperature, the difference between inside and outside temperature, roof surface temperature, solar intensity, relative humidity, and wind speed. Of all these variables the regressions against outside temperature and the difference between inside and outside temperature showed strong statistical results. For the rest of this analysis, we used the regressions against the difference between inside and outside temperature, since the regression statistics were slightly better. (The regression statistics against the roof surface temperature in general were poor since the range in surface temperature for the post-retrofit data is much narrower than the pre-retrofit data.) Also, to improve the regressions, we excluded the periods in 
which the internal loads differed from typical operation. In Battle Mountain the excluded data were June 1029. ${ }^{\dagger}$ These regressions are summarized and plotted in Figure 6.

As expected, the daily energy use for pre- and post-coating periods is very close for both buildings. We used correlations in Figure 6 to estimate the difference in AC energy use for the Pre and Post periods. The correlations for pre-retrofit (post-retrofit) conditions were used with the measured post-retrofit (pre-retrofit) temperature data to estimate electricity use for the post-retrofit (pre-retrofit) period. The difference between the measured $\mathrm{AC}$ use and the estimates through correlations showed the savings. These results are summarized in Figure 7.

In the Carlin building, the average estimated difference in AC energy use between the Pre and Post periods is about $0.76( \pm 0.18) \mathrm{kWh}$ per day. This compares with the earlier rough estimate of savings of about $0.4 \mathrm{kWh}$ per day, using the one-dimensional formula for steady-state heat conduction through the roof. The estimated savings for over $90 \%$ of the days are in the range of $0.53-1.00 \mathrm{kWh}$ per day. For the Battle Mountain building, average estimated savings are about $0.44 \mathrm{kWh}( \pm 0.25) \mathrm{kWh}$ per day, compared to 0.4 $\mathrm{kWh}$ estimated using the heat conduction formula. Obviously, since the Battle Mountain building was not heated during this period, the negative savings shown in Figure 7 are the results of the statistical analysis. In this building, we estimated positive savings for over $88 \%$ of the days.

\section{Analysis of Hourly Air-Conditioning Energy Use}

We also estimated savings from the regressions of hourly AC energy use vs. the outside/inside temperature difference; these regressions are presented in Figure 8. For both buildings the slope of the fits was about the same in pre- and post-coating periods (Battle Mountain $46.1 \mathrm{~W} / \mathrm{K}$ vs. $46.4 \mathrm{~W} / \mathrm{K}$ ) and for Carlin $62.6 \mathrm{~W} / \mathrm{K}$ vs. $61.9 \mathrm{~W} / \mathrm{K}$, a difference of about $1 \%$ in slopes). We do not consider these differences between the pre- and post-retrofit periods statistically significant. The regressions' intercepts for both buildings were

\footnotetext{
${ }^{\dagger}$ We initially tried to use the excluded data by adjusting the air-conditioning energy use for the changes in the interior load, using an estimate of the COP of the AC system from the normal operation of the building. However, the errors introduced through this approach were larger than the advantages of having more data points.
} 
lower (by about 20W/hour) in the post-coating than those of the pre-coating (Battle Mountain: Pre $=1.500 \mathrm{~kW}$ vs. Post: $1.481 \mathrm{~kW}$; Carlin: $1.397 \mathrm{~kW}$ vs. Post $=1.374 \mathrm{~kW})$.

We used the regression coefficients to estimate differences in energy use between the pre- and postcoating periods (using the outside-inside temperature difference as a predictor); the results are shown in Table 3. The mean and median hourly savings for Battle Mountain and Carlin are $19( \pm 6) \mathrm{Wh} / \mathrm{h}$ and $24( \pm 3) \mathrm{Wh} / \mathrm{h}$, respectively. The daily savings are estimated at $0.46( \pm 0.14) \mathrm{kWh}$ and $0.58( \pm 0.07) \mathrm{kWh}($ the average for these two buildings is about $0.52 \mathrm{kWh} /$ day). These savings compare well with savings of $0.4 \mathrm{kWh}$ per day roughly estimated from the heat conduction formula. In Table 4, we have also compared the daily electricity savings in this study with findings reported in the literature.

\section{Annual Air-Conditioning Energy Savings}

The non-air-conditioning energy-use intensity in these small buildings is very high, ranging from 58$66 \mathrm{kWh} /$ day $\left(160-180 \mathrm{~W} / \mathrm{m}^{2}\right)$. As a result, the buildings need to be air-conditioned for most of the year in order to keep the interior temperature below $26.7^{\circ} \mathrm{C}$. In Figures 6 and 8, using the developed correlation for each building, we calculated a balance temperature difference (defined as the ratio of Intercept and Slope) above which air-conditioning is required. According to the daily data, when the average daily outside temperature is less than $22-27 \mathrm{~K}$ cooler than inside temperature, air-conditioning is required. The corresponding balance temperature difference using the hourly correlation is $24-30 \mathrm{~K}$. Hence, for an inside cooling thermostat setting of $26.7^{\circ} \mathrm{C}$, air-conditioning is required when the average daily outside temperature is above $0-6^{\circ} \mathrm{C}$, or when the hourly temperature is above -3 to $4^{\circ} \mathrm{C}$. Using typical meteorological data, we calculated the annual cooling and heating degree-days (CDD, HDD) for a daily base temperature of $0^{\circ} \mathrm{C}$ and $5^{\circ} \mathrm{C}$ (Table 5). The average annual CDD is about 2450-3700 and the average annual HDD is about 450-1050, indicating that the building requires a significant amount of cooling throughout the year because of high internal loads. In fact, we estimate that these building are cooled about 200-250 days of the year (days with an average temperature above $0^{\circ} \mathrm{C}$ and $5^{\circ} \mathrm{C}$, respectively). Thus, the estimated total annual savings from the application of cool roofs are roughly 100-125kWh (0.5 kWh/day x 200-250 days). 


\section{Summary and Conclusions}

Energy use and environmental parameters were monitored in two AT\&T regeneration buildings during the summer of 2000 (June 10 to October 5). These buildings are constructed of concrete and are about $14.9 \mathrm{~m}^{2}$ in size. The buildings were initially monitored for about $11 / 2$ months (June 10 to about July 25 ) to establish a base condition. The originally green roofs of the buildings were then painted with a white coating (July 25 to July 27) and the monitoring was continued. The original roof reflectivities were about 26\%; after the application of the roof coatings, the reflectivities increased to about $72 \%$.

In both buildings, the analysis of monitored hourly data showed savings of about $0.5 \mathrm{kWh}$ per day (33

$\mathrm{Wh} / \mathrm{m}^{2}$ ). Since these building are air-conditioned over 250 days of the year, the annual energy savings are estimated at about $125 \mathrm{kWh}\left(8.4 \mathrm{kWh} / \mathrm{m}^{2}\right)$. The estimated annual savings are about $100-125 \mathrm{kWh}$ per year; at $\$ 0.1 / \mathrm{kWh}$, savings are about $\$ 10-12.5$ per year $\left(\$ 0.67-0.84 / \mathrm{m}^{2}\right.$ per year). It obviously cost significantly more than this amount to coat the roofs with a reflective coating, particularly because of the remote locations of these buildings. However, since the pre-fabricated roofs are already painted green at the factory, painting them a white (reflective) color would bring no additional cost. Hence, a reflective roof saves energy at no incremental cost.

It is also interesting to note that in buildings with high internal loads, the relative benefits of cool roofs and roof and wall insulations are not that clear. As the analysis showed, these buildings need to be air-conditioned for over 200 days per year. The insulation reduces AC use in those hours (and days) that the outside temperature is higher than the inside temperature. But for many hours (and days) during the year when the outside temperature is lower than inside temperature, insulation will retard the heat loss through the building shell and hence negatively impact AC usage. The effect of insulation is more pronounced when the roof is dark. Careful design with respect to roof 
insulation and roof reflectivity would minimize the cooling- and heating-energy use in these buildings.

\section{Acknowledgements}

This work was supported by AT\&T, the U.S. Environmental Protection Agency (EPA) under IAG No. DW89938442-01-2, and by the Assistant Secretary for Energy Efficiency and Renewable Energy, Building Technologies, of the US Department of Energy (DOE) under contract No. DEAC03-76SF00098. The authors would like to thank Mr. Bart Miller and other staff at AT\&T for assistance throughout this project. The author acknowledges the assistance of Leo Rainer (Davis Energy Group) in installing instrument to monitor buildings and collecting data, and of Ronnen Levinson for the preparation of graphs.

\section{References}

[1] Akbari H., Bretz S, Kurn D, Hanford J. Peak Power and Cooling Energy Savings of High-Albedo Roofs. Energy and Buildings 1997; 25:117-126.

[2] Konopacki S, Akbari H, Gartland L, Rainer L. Demonstration of Energy Savings of Cool Roofs. Report number LBNL-40673. Berkeley, CA: Lawrence Berkeley National Laboratory, 1998.

[3] Parker D, Huang J, Konopacki S, Gartland L, Sherwin J, Gu L. Measured and Simulated Performance of Reflective Roofing Systems in Residential Buildings. ASHRAE Transactions 1998 104(1): 963-975.

[4] Parker D, Sonne J, Sherwin J. Demonstration of Cooling Savings of Light Colored Roof Surfacing in Florida Commercial Buildings: Retail Strip Mall.” Report number FSEC-CR-964-97. Cocoa, FL: Florida Solar Energy Center, 1997.

[5] Hildebrandt E., Bos W, Moore R. Assessing the Impacts of White Roofs on Building Energy Loads. ASHRAE Technical Data Bulletin 1998; 14(2).

[6] Akridge, J. High-Albedo Roof Coatings - Impact on Energy Consumption. ASHRAE Technical Data Bulletin 1998; 14(2). 
[7] Boutwell, C. and Y. Salinas. 1986. "Building for the Future-Phase I: An Energy Saving Materials Research Project." Oxford: Mississippi Power Co., Rohm and Haas Co. and the University of Mississippi.

[8] Simpson JR, McPherson EG. The Effect of Roof Albedo Modification on Cooling Loads of Scale Residences in Tucson, Arizona. Energy and Buildings 1997; 25:127-137.

[9] Konopacki S, Akbari H. Simulated Impact of Roof Surface Solar Absorptance, Attic, and Duct Insulation on Cooling and Heating Energy Use in Single-Family New Residential Buildings. Report number LBNL41834. Berkeley, CA: Lawrence Berkeley National Laboratory, 1998.

[10] Akbari H., Konopacki S, Eley C, Wilcox B, Van Geem M, Parker D. Calculations for Reflective Roofs in Support of Standard 90.1. ASHRAE Transactions 1998; 104(1): 984-995.

[11] Gartland, L., S. Konopacki and H. Akbari. 1996. "Modeling the Effects of Reflective Roofing." Proceedings, ACEEE 1996 Summer Study on Energy Efficiency in Buildings 4:117-124. Pacific Grove, CA.

[12] Konopacki S, Akbari H, Pomerantz M, Gabersek S, Gartland L. Cooling Energy Savings Potential of Light-Colored Roofs for Residential and Commercial Buildings in 11 U.S. Metropolitan Areas. Report number LBNL-39433. Berkeley, CA: Lawrence Berkeley National Laboratory, 1997.

[13] Konopacki S, Akbari H. Energy Savings Calculations for Heat Island Reduction Strategies in Baton Rouge, Sacramento and Salt Lake City. Report number LBNL-42890. Berkeley, CA: Lawrence Berkeley National Laboratory, 2000.

[14] Konopacki S, Akbari H. Measure Energy Savings and Demand Reduction from a Reflective Roof Membrane on a Large Retail Store in Austin. Report number LBNL-47149. Berkeley, CA: Lawrence Berkeley National Laboratory, 2001. 
Figure 1: Typical Regen Building.

Figure 2: Monitoring Point Locations. The measurement points include outside air temperature (Toa); relative humidity (R); wind speed and wind direction (Wspd, Wdir); horizontal solar insolation (Hsol); roofsurface and under-roof-surface temperatures (Trs, Tru) at two locations (A and B); attic-air temperature (Taa); inside air temperature (Tai); and air-conditioning and whole-building electricity use (WAC, Wtot).

Figure 3. Hourly temperature plots of the roof surface, under-roof, attic air, and outside air for the three sites monitored. Hourly plots include a week before and after the roof was coated.

Figure 4. Average daily [a] and hourly [b] rises of roof surface temperature Trs, roof undersurface temperature Tru, and attic-air temperature Taa above outside air temperature Toa. Average hourly plots include a week before and after the roof was coated.

Figure 5. Daily [a] and hourly [b] total, air-conditioning (AC), and non-air-conditioning (Non-AC) energy consumption.

Figure 6. Daily AC energy use vs. outside-inside temperature for pre- and post-coating.

Figure 7. Daily energy savings at Battle Mountain and Carlin from the application of reflective roof coatings. Lines represent $10^{\text {th }}, 25^{\text {th }}, 50^{\text {th }}, 75^{\text {th }}$, and $90^{\text {th }}$ percentiles; symbols are means.

Figure 8 . Hourly AC energy use vs. outside-inside temperature for pre- and post-coating. 
Table 1. Internal Loads and Characteristics of the Air-Conditioning Equipment.

\begin{tabular}{lllll} 
& & AC Equipment & \\
\cline { 3 - 5 } Site & $\begin{array}{l}\text { Internal } \\
\text { Load }(\mathrm{kW})\end{array}$ & Model & $\begin{array}{l}\text { Capacity } \\
(\mathrm{kWt})\end{array}$ & $\mathrm{COP}$ \\
\hline Battle Mountain & 2.486 & 2 x Carrier YCB243D & 6.89 & 2.5 \\
Carlin & 2.337 & 2 x Carrier YCB243D & 6.89 & 2.5
\end{tabular}


Table 2. Monitoring Points

\begin{tabular}{lllll} 
Point & Name & Location & Purpose & Signal \\
\hline 1 & TRS-A & Roof surface at A & Roof surface temperature & type T \\
2 & TRS-B & Roof surface at B & Roof surface temperature & type T \\
3 & TRU-A & Roof underside at A & Roof underside temperature & type T \\
4 & TRU-B & Roof underside at B & Roof underside temperature & type T \\
5 & TAA & Middle of attic & Attic air temperature & type T \\
6 & TAI & Wall at environmental panel & Interior air temperature & type T \\
7 & TAO & Weather tower & Outdoor dry bulb temperature & $0-1$ VDC \\
8 & RHO & Weather tower & Outdoor relative humidity & $0-1$ VDC \\
9 & WSPD & Weather tower & Wind speed & Pulse \\
10 & WDIR & Weather tower & Wind direction & $0-5$ VDC \\
11 & HSOL & Weather tower & Horizontal solar radiation & $0-100 \mu \mathrm{A}$ \\
12 & WAC & Panelboard & Total AC power & Pulse \\
13 & WTOT & Panelboard & Total building power & Pulse
\end{tabular}


Table 3. Mean and median hourly savings $(\mathrm{kWh} / \mathrm{h})$.

Battle

Savings (kWh/h) $\quad$ Carlin $\quad$ Mountain

Min

$0.017 \quad 0.004$

5-percentile $\quad 0.020 \quad 0.010$

10-percentile $\quad 0.020 \quad 0.011$

$\begin{array}{lll}\text { 1-quartile } & 0.022 & 0.014\end{array}$

$\begin{array}{lll}\text { Med } & 0.024 & 0.019\end{array}$

$\begin{array}{lll}\text { Mean } & 0.024 & 0.019\end{array}$

3-quartile $\quad 0.026 \quad 0.024$

90-percentile $\quad 0.028 \quad 0.027$

95-percentile $\quad 0.029 \quad 0.028$

$\begin{array}{lll}\text { Max } & 0.031 & 0.032\end{array}$ 
Table 4. Comparison of measured summertime air-conditioning daily energy savings from application of reflective roofs. $\Delta \mathrm{a}$ is change is roof reflectivity, $\mathrm{RB}$ is radiant barrier, duct is the location of air-conditioning ducts, and R-val is R-value in K. $\mathrm{m}^{2} / \mathrm{W}$.

\begin{tabular}{|c|c|c|c|c|c|c|}
\hline \multirow[t]{2}{*}{ Location } & \multirow[t]{2}{*}{ Building type } & \multirow{2}{*}{$\begin{array}{c}\text { Roof area } \\
{\left[\mathrm{m}^{2}\right]}\end{array}$} & \multicolumn{3}{|c|}{ Roof system } & \multirow{2}{*}{$\begin{array}{c}\text { Daily savings } \\
{\left[\mathrm{Wh} / \mathrm{m}^{2}\right]}\end{array}$} \\
\hline & & & R-val & duct & $\Delta \mathrm{a}$ & \\
\hline \multicolumn{7}{|l|}{ California } \\
\hline Davis [2] & Medical Office & 2,945 & 1.4 & Interior & 0.36 & 68 \\
\hline Gilroy [2] & Medical Office & 2,211 & 3.3 & Plenum & 0.35 & 39 \\
\hline San Jose [2] & Retail Store & 3,056 & $\mathrm{RB}$ & Plenum & 0.44 & 4.3 \\
\hline Sacramento [1] & School Bungalow & 89 & 3.3 & Ceiling & 0.60 & 47 \\
\hline Sacramento [5] & Office & 2,285 & 3.3 & Plenum & 0.40 & 14 \\
\hline Sacramento [5] & Museum & 455 & 0 & Interior & 0.40 & 20 \\
\hline Sacramento [5] & Hospice & 557 & 1.9 & Attic & 0.40 & 11 \\
\hline \multicolumn{7}{|l|}{ Florida } \\
\hline Cocoa Beach [4] & Strip Mall & 1,161 & 1.9 & Plenum & 0.46 & 7.5 \\
\hline Cocoa Beach [4] & School & 929 & 3.3 & Plenum & 0.46 & 43 \\
\hline \multicolumn{7}{|l|}{ Georgia } \\
\hline Atlanta [6] & Education & 1,115 & 1.9 & Plenum & N/A & 75 \\
\hline \multicolumn{7}{|l|}{ Nevada } \\
\hline Battle Mountain & Regeneration & 14.9 & 3.2 & None & 0.45 & 31 \\
\hline Carlin & Regeneration & 14.9 & 3.2 & None & 0.45 & 39 \\
\hline \multicolumn{7}{|l|}{ Texas } \\
\hline Austin [14] & Retail Store & 9,300 & 2.1 & Plenum & 0.70 & 39 \\
\hline
\end{tabular}


Table 5. Annual Heating and Cooling Degree-Days Base $0^{\circ} \mathrm{C}$ and $5^{\circ} \mathrm{C}$

\begin{tabular}{lrrrr} 
& \multicolumn{2}{c}{ Heating Degree-Days } & \multicolumn{2}{c}{ Cooling Degree-Days } \\
\cline { 2 - 5 } Location & Base $0^{\circ} \mathrm{C}$ & Base $5^{\circ} \mathrm{C}$ & Base $0^{\circ} \mathrm{C}$ & Base $5^{\circ} \mathrm{C}$ \\
\hline Battle Mountain & 364 & 900 & 3952 & 2664 \\
Carlin & 551 & 1195 & 3423 & 2242 \\
Average & 457 & 1047 & 3687 & 2453
\end{tabular}




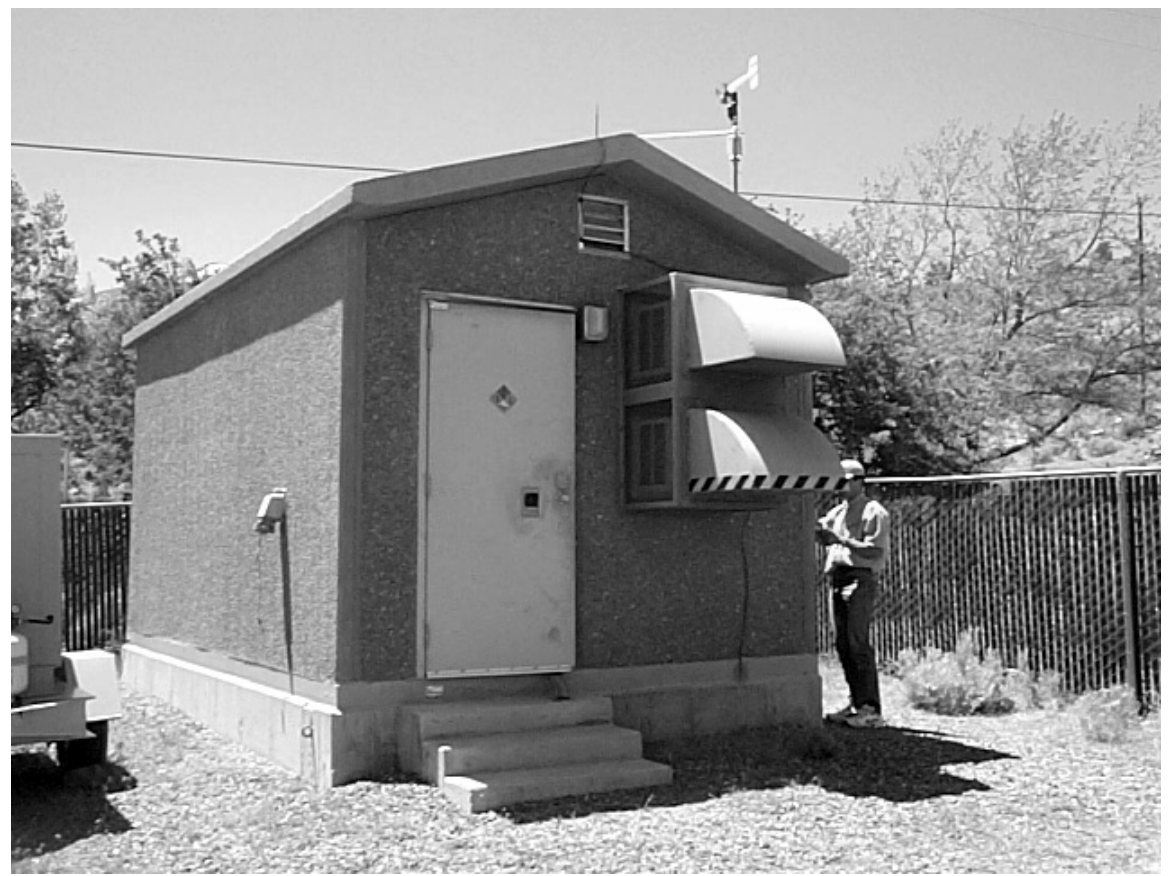

Figure 1: Typical Regen Building. 


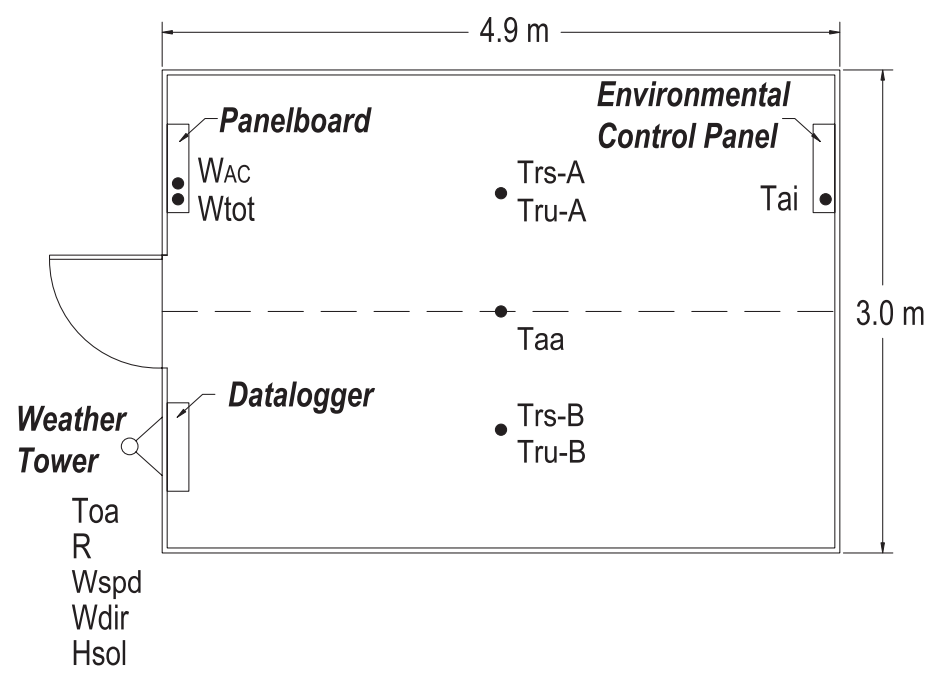

Figure 2: Monitoring Point Locations. The measurement points include outside air temperature (Toa); relative humidity (R); wind speed and wind direction (Wspd, Wdir); horizontal solar insolation (Hsol); roofsurface and under-roof-surface temperatures (Trs, Tru) at two locations (A and B); attic air temperature (Taa); inside air temperature (Tai); and air conditioning and total building electricity use (WAC, Wtot). 
Battle Mountain
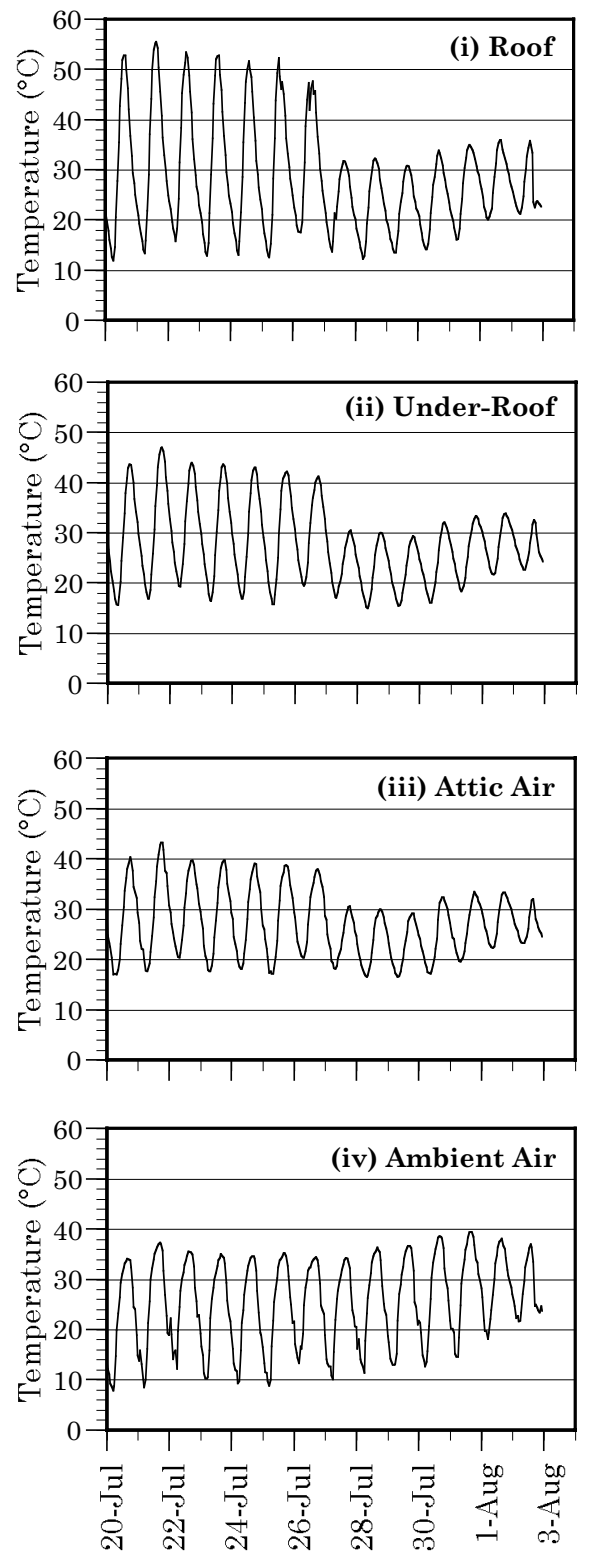

\section{Carlin}
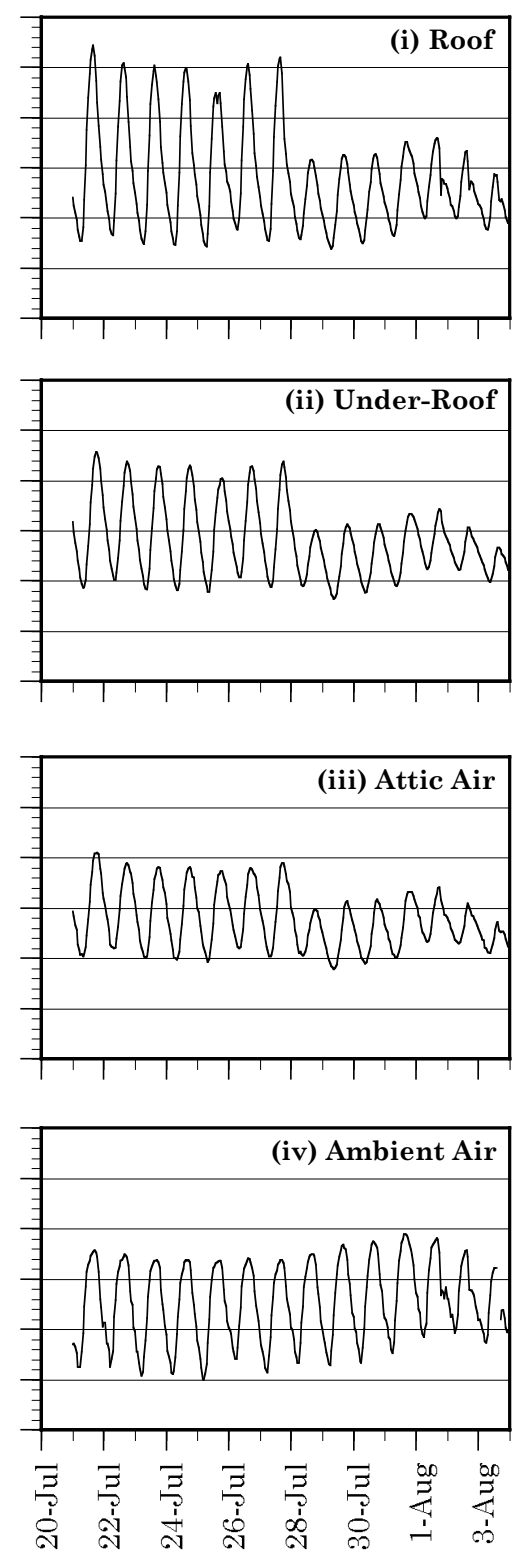

Figure 3. Hourly temperature plots of the roof surface, under-roof, attic air, and outside air for the three sites monitored. Hourly plots include a week before and after the roof was coated. 
(a)
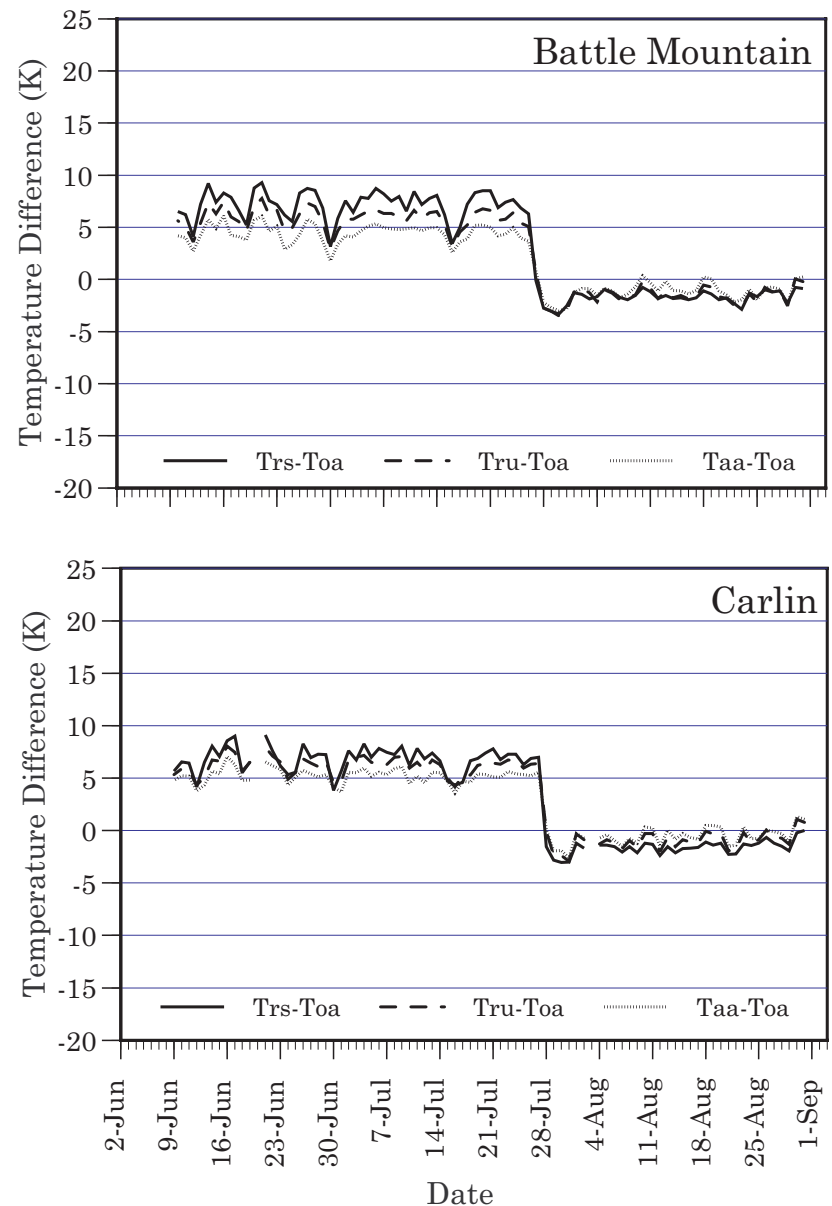

(b)
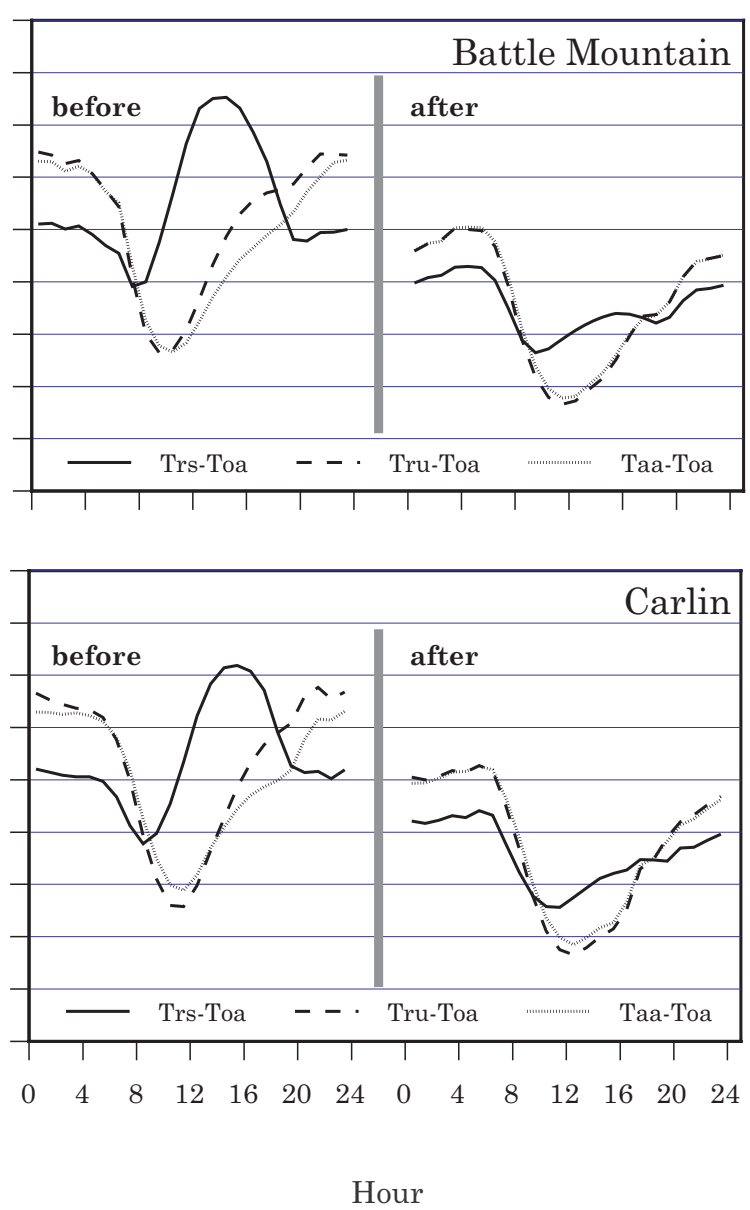

Figure 4. Average daily [a] and hourly [b] rises of roof surface temperature Trs, roof undersurface temperature Tru, and attic-air temperature Taa above outside air temperature Toa. Average hourly plots include a week before and after the roof was coated. 
(a)
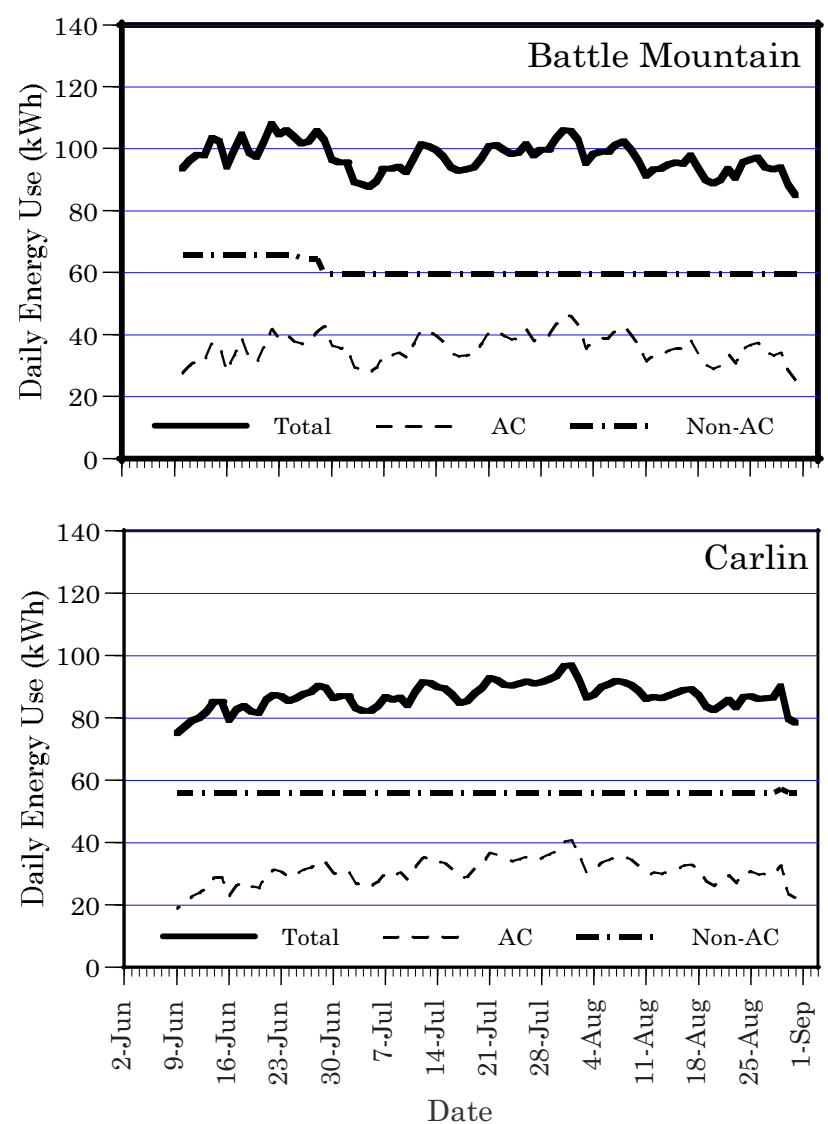

(b)
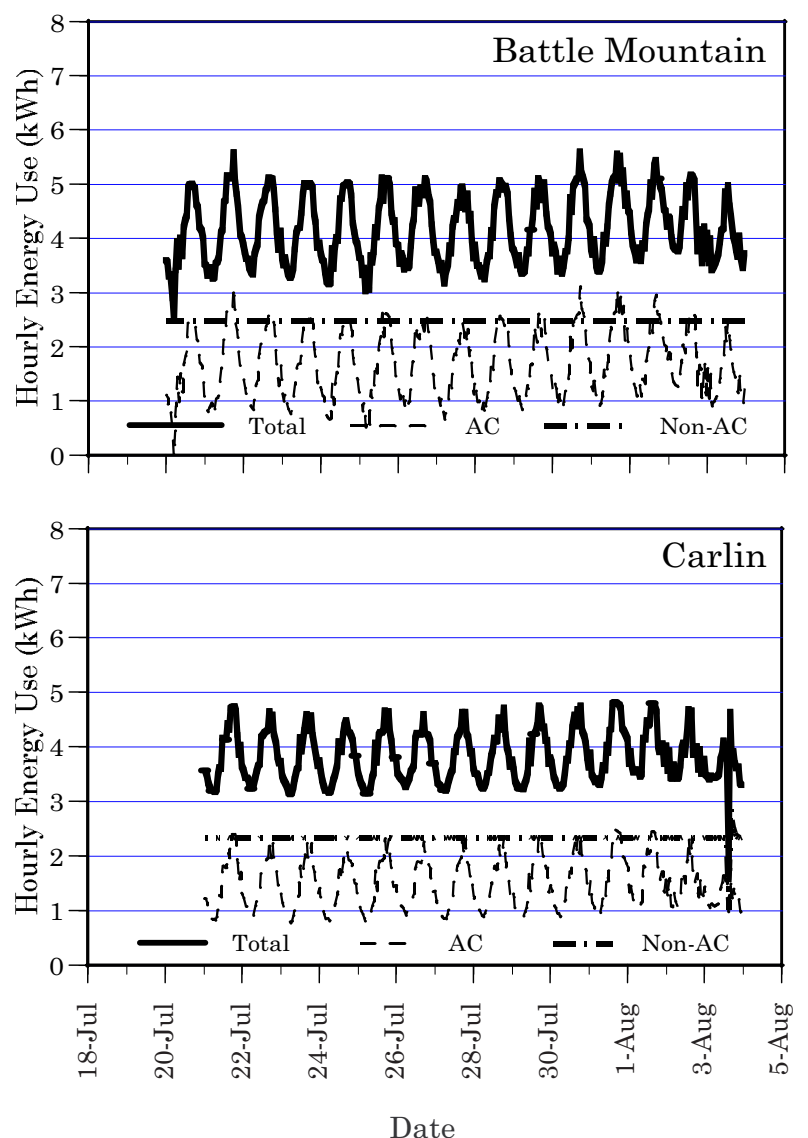

Figure 5. Daily [a] and hourly [b] total, air-conditioning (AC), and non-air-conditioning (Non-AC) energy consumption. 

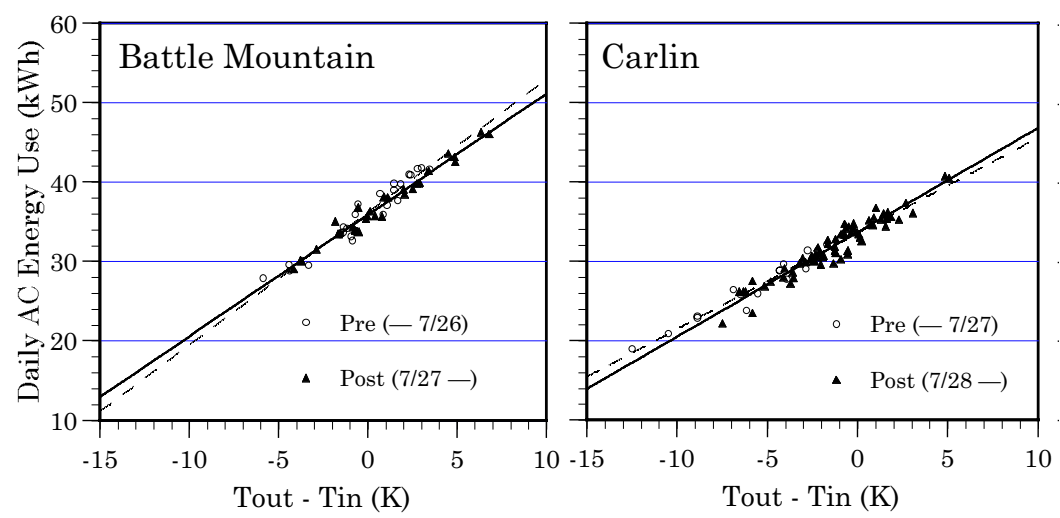

\begin{tabular}{lcccc} 
& \multicolumn{2}{c}{ Battle Mountain } & \multicolumn{2}{c}{ Carlin } \\
\cline { 2 - 5 } & Pre & Post & Pre & Post \\
\hline $\mathrm{R}^{2}$ & 0.93 & 0.97 & 0.94 & 0.95 \\
Intercept $(\mathrm{kWh})$ & 36.29 & 35.83 & 33.93 & 33.31 \\
Slope $(\mathrm{kWh} / \mathrm{K})$ & 1.669 & 1.528 & 1.247 & 1.307 \\
Balance Temp. & -21.7 & -23.4 & -27.2 & -25.5 \\
Diff. $(\mathrm{K})$ & & & &
\end{tabular}

Figure 6. Daily AC energy use vs. outside-inside temperature for pre- and post-coating. 


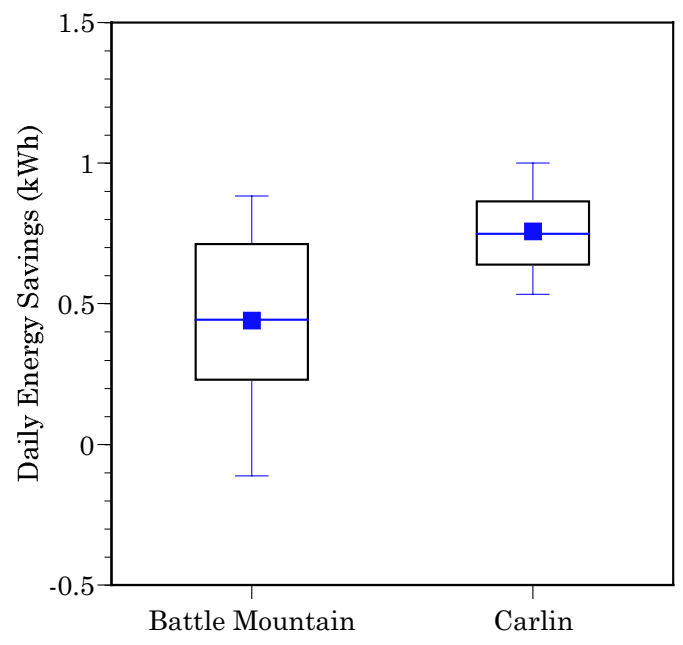

Figure 7. Daily energy savings at Battle Mountain and Carlin from the application of reflective roof coatings. Lines represent $10^{\text {th }}, 25^{\text {th }}, 50^{\text {th }}, 75^{\text {th }}$, and $90^{\text {th }}$ percentiles; symbols are means. 

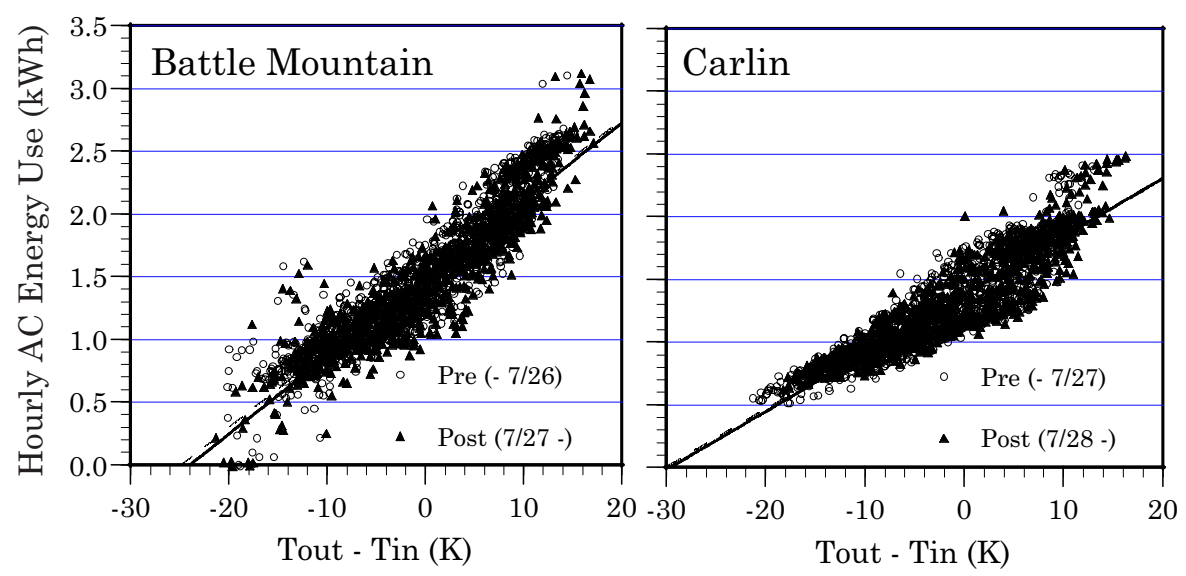

\begin{tabular}{lcccc}
\hline & \multicolumn{2}{c}{ Battle Mountain } & \multicolumn{2}{c}{ Carlin } \\
\cline { 2 - 5 } $\mathrm{R}^{2}$ & Pre & Post & Pre & Post \\
Intercept $(\mathrm{kWh})$ & 0.87 & 0.85 & 0.83 & 0.83 \\
Slope $(\mathrm{Wh} / \mathrm{K})$ & 1.500 & 1.481 & 1.397 & 1.374 \\
Balance Temp. & 62.6 & 61.9 & 46.1 & 46.4 \\
Diff. $(\mathrm{K})$ & -24.0 & -23.9 & -30.3 & -29.6
\end{tabular}

Figure 8. Hourly AC energy use vs. outside-inside temperature for pre- and post-coating. 